\title{
Research on the internal development human resource management system
}

\author{
Gao Xiao ${ }^{1}$, Wang Xiaoxi ${ }^{1}$, Huang Xiaobo ${ }^{2}$, Lv Pin $^{2}$, Huo Ningning $^{2}, \mathrm{Xu} \mathrm{Xiao}^{2}$, \\ Wang $\mathrm{Fa}^{3}$ \\ 1, State Grid Liaoning Electric Power Co., Ltd. , China; \\ 2,State Grid Liaoning Electric Power Co., Ltd. Liaoyang power supply company, China;
}

3,Deng Ta Land Resource Bureau

\begin{abstract}
Keywords: internal development human resource management system; questionnaire survey; variance analysis
\end{abstract}

\begin{abstract}
Internal development human resource management system is a system which originated in Japan is considered a high performance human resource management system. A large number of Chinese enterprises, especially the state-owned monopoly enterprise have the typical characteristics of the internal development type; the change of human resource management practices of research in today's market is to provide reference for the enterprise human resource practice decision. This paper uses the method of questionnaire survey to get the relevant data of the enterprise. The relationship between single factor and internal development human resource management system was analyzed by the method of variance analysis. Finally found that the size, the nature, the special capacity of the enterprise are closely related to the internal development of human resource management system
\end{abstract}

\section{Background}

With the development of the times, the theory and practice of human resource management has been widely studied. The idea of people oriented has been gradually carried out ${ }^{[1]}$. After 30 years of reform the state-owned enterprises have achieved a certain effect of reformat present. However, the voice of the reform of state-owned enterprises has never stopped, especially in the monopoly of power, telecommunications, finance, oil, petrochemical, tobacco industry, the voice of reform is more urgent and complex ${ }^{[2]}$. Enterprise reform must be accompanied by changes in human resources measures. This paper tries to study the internal development human resource system from the angle of strategic human resource management, and to explore the trend of the change of human resource management practices. To adjust the management system in order to promote the development of enterprises have a good reference value.

\section{Definition of internal development human resource management system}

Internal development system has obvious organization of the internal labor market and features of long term employment. Organizations are willing to invest time and resources in the cultivation of employees, but also hope that employees can be loyal to the organization, and thus produce long-term contribution ${ }^{[3]}$. Its human resource measures include: recruitment company low-level employees, priority by the internal recruitment staff, recruitment and selection, providing extensive socialization training and performance assessment to act as basis, less use of incentives and inducements, employment security, and more opportunities to employees in with their own decision ${ }^{[4]}$.

\section{Research method}

This paper studies the characteristics and connotation of the internal development human resource management system, and further analyzes the differences between different enterprises. Therefore, the methods of theoretical research and empirical research are used in this study. On the basis of 
literature research, the characteristics of the internal development human resource management system are derived; To explore the use of the situation, and the design of the questionnaire, and then carry out a questionnaire survey; The survey results were analyzed by using the relevant data statistics method; The change trend of human resource management system resulted from the change situation. At first, reference to other people's questionnaires and own research needs to design a questionnaire, specific content as shown in Table $1^{[5]}$.

Table 1 Specific content of the questionnaire

\begin{tabular}{|c|c|c|c|c|c|}
\hline question & \multicolumn{5}{|c|}{ answer } \\
\hline What is your position & $\begin{array}{l}\text { senior } \\
\text { manageme } \\
\text { nt }\end{array}$ & $\begin{array}{l}\text { middle } \\
\text { manageme } \\
\text { nt }\end{array}$ & $\begin{array}{l}\text { front-line } \\
\text { managers }\end{array}$ & other & \\
\hline $\begin{array}{l}\text { What is the nature of the } \\
\text { company }\end{array}$ & $\begin{array}{l}\text { state-owne } \\
\text { d }\end{array}$ & $\begin{array}{l}\text { privately } \\
\text { operated }\end{array}$ & $\begin{array}{l}\text { foreign } \\
\text { capital }\end{array}$ & $\begin{array}{c}\text { joint } \\
\text { venture }\end{array}$ & $\begin{array}{l}\text { oth } \\
\text { er }\end{array}$ \\
\hline $\begin{array}{c}\text { How large is the scale of } \\
\text { enterprises }\end{array}$ & $\begin{array}{l}\text { micro } \\
\text { enterprises }\end{array}$ & $\begin{array}{l}\text { small } \\
\text { enterprises }\end{array}$ & $\begin{array}{l}\text { medium-s } \\
\text { ized } \\
\text { enterprise } \\
\text { s }\end{array}$ & $\begin{array}{l}\text { large } \\
\text { enterpri } \\
\text { ses }\end{array}$ & \\
\hline $\begin{array}{c}\text { The company has a strong } \\
\text { comprehensive management } \\
\text { capabilities }\end{array}$ & 1 & 2 & 3 & 4 & 5 \\
\hline $\begin{array}{c}\text { The company has a strong } \\
\text { financial management } \\
\text { capabilities }\end{array}$ & 1 & 2 & 3 & 4 & 5 \\
\hline $\begin{array}{l}\text { The company has a strong } \\
\text { market or sales capacity }\end{array}$ & 1 & 2 & 3 & 4 & 5 \\
\hline $\begin{array}{l}\text { The company has a strong } \\
\text { research capability }\end{array}$ & 1 & 2 & 3 & 4 & 5 \\
\hline $\begin{array}{c}\text { The company has a strong } \\
\text { production capacity }\end{array}$ & 1 & 2 & 3 & 4 & 5 \\
\hline
\end{tabular}

In Table 1,1,2,3,4,5 means the degree of compliance to the problem from low to high, 1 of them indicated that the degree of compliance is lowest, 5 is highest. After the completion of the questionnaire, the teachers and students from the human resource management center assist in payment. Most of the subjects were students of MBA or EMBA classes, after they completing the questionnaire, teachers recovered the questionnaire on the spot and prompt them to fill in the complete. After getting the results of the questionnaire, we can analyze the data.

\section{Data analysis and results}

A total of 750 questionnaires were issued and 587 valid questionnaires were recovered. In this survey, the effective questionnaire rate was $78.26 \%$. The sample is shown in Table 2.

Table 2 The sample basic situation

\begin{tabular}{cccc}
\hline & the sample basic situation & frequency & $\begin{array}{c}\text { percentag } \\
\text { e }\end{array}$ \\
\hline Position in & senior & 121 & 20.6 \\
company & middle & 236 & 40.2 \\
& front-line & 161 & 27.4 \\
& other & 69 & 11.8 \\
scale of the & micro & 58 & 9.9 \\
company & small & 89 & 15.2 \\
& medium-sized & 194 & 33 \\
\hline
\end{tabular}




\begin{tabular}{cccc}
\hline & large & 246 & 41.9 \\
nature of the & state-owned & 147 & 25 \\
company & privately operated & 304 & 51.8 \\
& foreign capital & 52 & 8.8 \\
& joint venture & 23 & 3.9 \\
& other & 61 & 10.5 \\
\hline
\end{tabular}

Variance analysis, also called variance analysis or $\mathrm{F}$ test, is one of the commonly used methods to deal with test results in quantity statistics [6]. In this paper, the internal development of human resources management system related content and sample variance analysis.

a. research on the relationship between enterprise scale and internal development human resource management system. In this paper, 100 people hereinafter referred to as micro enterprises; 100 to 500 people are called small enterprises; 500 to 5000 people are called medium-sized enterprises; More than 5000 people are called large enterprises. In order to study the effect of enterprise scale on the use of human resources management system is different, the SPSS17.0 was use to analyze the variance of organizational performance and scale of enterprises. The results are shown in Table 3.

Table 3 Variance analysis of enterprise scale to human resource management system

\begin{tabular}{cccccccc}
\hline \multirow{2}{*}{ variable } & $\begin{array}{c}\text { Sample } \\
\text { quantity }\end{array}$ & average & $\begin{array}{c}\text { standard } \\
\text { deviation }\end{array}$ & $\begin{array}{c}\text { Measure } \\
\text { ment } \\
\text { variables }\end{array}$ & F & Sig. \\
\hline \multirow{2}{*}{ Enterpri } & $\begin{array}{c}\text { large } \\
\text { Medium-s }\end{array}$ & 246 & 4.01 & 0.35 & & & \\
ses scale & ized & 194 & 3.99 & 0.39 & HRM & 25.3 & .000 \\
& small & 89 & 3.96 & 0.46 & & 4 & \\
& micro & 58 & 3.87 & 0.51 & & & \\
\hline
\end{tabular}

It can be seen from the above table, $\mathrm{F}$ is $25.32, \mathrm{P}$ is 0.000 , and the results were significant. It is shows that the internal development human resource management system in different scale of enterprises have significant differences, the larger the size of the enterprise, the greater the average value. This result means that the larger the enterprise scale, the more inclined to use the internal development system.

b. research on the relationship between enterprise nature and internal development human resource management system. In China, there is a big difference in the performance of enterprises with different nature. Especially since the reform and opening up, the rapid development of state-owned enterprises, and private enterprises into the plight of the financing difficulties. In this study, a sample of the nature of all kinds of enterprises is collected. Variance analysis of the results of the different nature of the enterprise human resources management system using the internal development type, the results are shown in table 4.

Table 4 Variance analysis of human resource management system in enterprise nature

\begin{tabular}{lccccccc}
\hline & variable & $\begin{array}{c}\text { Sample } \\
\text { quantit } \\
\mathrm{y}\end{array}$ & $\begin{array}{c}\text { avera } \\
\text { ge }\end{array}$ & $\begin{array}{c}\text { standar } \\
\text { deviatio } \\
\mathrm{n}\end{array}$ & $\begin{array}{c}\text { Measure } \\
\text { ment } \\
\text { variables }\end{array}$ & $\mathrm{F}$ & Sig. \\
\hline \multirow{2}{*}{ enterpris } & privately operated & 304 & 3.90 & 0.48 & & & \\
es nature & foreign capital & 52 & 3.81 & 0.50 & & 16. & .00 \\
& joint venture & 23 & 4.22 & 0.35 & & 91 & 3 \\
\hline
\end{tabular}

From the table can be seen, $\mathrm{F}=16.91, \mathrm{P}=0.003$, the test results are significant. Internal development human resource management system has significant differences in the nature of different enterprises.

c. research on the relationship between the special ability and the internal development human resource management system. The special ability of the industry is the advantage of the enterprise to participate in the competition of the organization, which can produce the core competence of the enterprise. In the present study, the effect of enterprise's special ability on human resource management system is tested through data checking. In the data obtained through questionnaire 
survey, the maximum number is 5 , the maximum number is 2.27 , the average is $3.99,25 \%$ quartile is $3.73,75 \%$ quartile is 4.45 . Integrating these data with statistical significance, variance analysis of different level of special ability of the enterprise, to observe whether there are differences, the results see Table 5.

Table 5 Variance analysis of human resource management system with special ability

\begin{tabular}{|c|c|c|c|c|c|c|c|}
\hline \multicolumn{2}{|c|}{ variable } & $\begin{array}{l}\text { Sample } \\
\text { quantity }\end{array}$ & $\begin{array}{c}\text { averag } \\
\text { e }\end{array}$ & $\begin{array}{l}\text { standard } \\
\text { deviation }\end{array}$ & $\begin{array}{l}\text { Measurement } \\
\text { variables }\end{array}$ & $\mathrm{F}$ & Sig \\
\hline speci & $\begin{array}{l}\text { very } \\
\text { low }\end{array}$ & 147 & 3.78 & 0.26 & \multirow{4}{*}{ HRM } & \multirow{4}{*}{$\begin{array}{c}29 . . \\
91\end{array}$} & \multirow{4}{*}{$\begin{array}{c}.00 \\
0\end{array}$} \\
\hline al & low & 304 & 3.92 & 0.23 & & & \\
\hline abilit & high & 52 & 4.21 & 0.27 & & & \\
\hline $\mathrm{y}$ & $\begin{array}{l}\text { very } \\
\text { high }\end{array}$ & 23 & 4.29 & 0.31 & & & \\
\hline
\end{tabular}

From the table can be seen, F-measure 29.88, $\mathrm{P}=.000$, variance test results in a significant range of 0.001, said the internal development of people resource system has significant difference in the special ability of different enterprises. It can be seen that with the enhancement of enterprise's special ability, the internal development of human resources management system scores gradually become larger.

\section{Conclusion}

The following conclusions are obtained through the research on the development of human resource management system in different enterprises. First, compared to small and medium-sized enterprises, large enterprises tend to use the internal development of human resource management system. Secondly, in terms of the nature of the enterprise, the use of the trend from high to low is Sino foreign joint ventures, state-owned enterprises, private enterprises, foreign-funded enterprises. Third, the more special organization ability, the more tend to use the internal development of human resource management system. These three conclusions can provide important guiding significance for enterprises in transition, so that the development of enterprises is becoming better and better.

\section{Reference}

[1] PecceiR ,Voorde K V D. Human Resource Management and Performance[M]// Wiley Encyclopedia of Management. John Wiley \& Sons, Ltd, 2015.

[2] Zeng X, Chen L, Su Z. The evolution of human resource management in China: traditions, reforms and developments[J]. Chapters, 2014.

[3] Li H. The Development of a Human Resource Management System[J]. Advanced Materials Research, 2014, 926-930(926-930):4020-4023.

[4] Torrington D. Human resource management[J]. Prentice Hall, 2015, 166(4230):898-899.

[5] Xin L I, Sun Q. The Effect of Strategic Human Resource Management on Employee's Intention to Retain_—Empirical Research on Questionnaire Survey of 151 Companies[J]. Science of Science \& Management of S \& T, 2010.

[6] Butt M. Variance analysis[J]. Accounting Auditing \& Accountability Journal, 2014, 23(6):816-816. 